\title{
GRAMMATICAL ERROR ANALYSIS ON THE FIRST GRADE OF OLYMPIAD STUDENT'S DESCRIPTIVE TEXT AT SMP ISLAM 02 PUJON
}

\author{
Atika Kurniafita \\ IKIP Budi Utomo \\ tikateezhar@gmail.com
}

\begin{abstract}
The following are the objectives of this study: 1. To define, classify, and explain the types of grammatical errors contained in descriptive texts written by first-grade Olympiad students at SMP ISLAM 02 Pujon using Dulay's Surface Strategy Taxonomy Theory. 2. To use H.Douglas Brown's Theory of Potential Sources of Error to classify the causes of mistakes created by students while writing descriptive text. The analysis was carried out using a descriptive qualitative approach. The researcher used guidance as an instrument to direct the student through the method of writing descriptive text, with the student's descriptive text serving as the data source. According to the results, the researcher discovered all types of errors and all types of sources, with omission being the most common form of error and intralingua being the most common source.
\end{abstract}

Keywords: Error, Grammatical Error, Error Analysis, Descriptive text

\section{Introduction}

English is a foreign language that students must study because it is commonly used as a medium of communication worldwide. Listening, listening, reading, and writing are the four skills that students are required to acquire while learning English. These skills help a person to interact in a variety of situations. However, many students feel that writing is a required ability. They still difficult to avoid making an error on their writing and Olympiad students are not the exception.

Because of the differences between the student's native language and the student's target language of grammatical rule, the difficulties can be caused by the student's lack of knowledge about English grammatical rules and how to use them properly in their writing. According to Brown (2007:76), errors identified as a result of the student's lack of understanding of the rule of language. Thus, some students also still have the problem to write in correct sentence based on English structure because the influence of their native language which lead them into some errors. Widiati and Cahyono (2006:139) argued that writing is a difficult skill to master. In writing, students should pay more attention on applying the general components of writing process and the important component that should be considered by the student is grammar. Grammar plays an important role in delivering text messages to make the text meaningful.

Grammar is an important part of any skill in English, especially writing skills (Toago et al., 2013:1). The subject, verb, article, noun, adjective, adverb, modifier, phrase, clause, object, and other parts of grammar are used to construct a sentence. As a result, students must pay careful attention to the use of grammar in their writing. Since grammar is not just about the form of the sentence, but also about the content, the text generated will be more meaningful and not ambiguous. Grammar is, in reality, regarded as the student's primary writing problem.

According to the junior high school's 2013 curriculum of this even 
semester 2019/2020, written in the first grade silabus of KD 4.7.2 "Siswa mampu menyusun teks deskriptif lisan dan tulis sangat pendek dan sederhana terkait orang, binatang dan benda dengan memerhatikan fungsi sosial, struktur teks, dan unsur kebahasaan sesuai konteks" said that students in the first grade of junior high school are asked to be able to write one of the text, descriptive text. However, many students at Islamic Junior High School 2 Pujon, especially those in the first grade of Olympiad students, have reported that they are still unsure how to use proper grammar and that they tend to disregard grammatical rules in their descriptive writing, resulting in errors. As a result, the researcher suggests that students also need to think more about how to apply the correct grammar.

For the reasons mentioned above, the researcher is interested in performing an examination as part of a study titled "Grammatical error analysis on the first grade of Olympiad student's descriptive text at SMP Islam 02 Pujon"

\section{Research Method}

This study is composed of descriptive qualitative analysis presented in the form of sentences and paragraphs. The researcher did not use a large number of statistics to evaluate the data in this study; instead, the researcher concentrated on analyzing the problems or cases of every error and potential cause of error found in descriptive text written by Olympiad Students in SMP ISLAM 2 PUJON in the first grade.

The researcher used Dulay theory (1982) to define, classify, and explain the forms of grammatical errors in writing descriptive text. Dulay theory (1982) categorizes errors into four types based on Surface Strategy Taxonomy. Omission, addition, misordering, and misformation are the four types of errors. Following that, the researcher examined and identified the potential causes of the students' errors.

This research is done on the first grade of Olympiad Students in SMP ISLAM 2 PUJON. In this research the instruction and direction paper that had been given to the students is became the tool or instrument for the researcher to retrieve the data, and the student's descriptive text is the data source.

\section{Result and Discussion}

The researcher examined 27 students' descriptive texts and discovered a variety of errors.

The first is an omission error, which is described as the absence of a required item or morpheme in a well-formed utterance (Dulay, 1982). The researcher discovered 44 omission error sentences based on the results of the students' writing text.

Most of the students omit be as the substitutive of a verb, but they also omit subject, be on passive sentence, omit articles, omit suffix s/es/ly, omit auxiliary verb has/have, omit object pronoun, omit preposition, and omit there transformation. For example: 'He teach sport' the correct sentence should be 'He teaches sport' Addition error. Second is addition error happens when the student adds unnecessary item which should not appear in a sentence. Based on the result, the researcher found 12 error sentences of addition which the most sentences consist of double marking error in using 'to be' and verb 1 together in an utterance. Some students also add the unwanted suffix/letter/object pronoun. For example: 'I am have a favorite blanket' the correct sentence should be 'I have a favorite blanket'. Third is Misformation error occurs in the most sentences too. Misformation error happens when the students supply the wrong morpheme, structure or word choice used in a sentence. The result found that in this research there were 39 error sentences 
which the students mislead on using the possessive adjective, substituting the auxiliary verb of plural noun into singular noun or singular noun into plural noun, mislead on using the subject or object pronoun or even mislead on using the word choice. For example: 'It have curved and red beak' the correct sentence should be 'It has curved and red beak'. Then, misordering error, it defines as the incorrect placement of the word, morpheme or structure in an utterance. Based on the analysis result, there were 12 error sentences of misordering which the students wrote in English sentence but they translate word by word based on the Indonesian word order. For example: '...four windows wide' the correct sentence should be '...four wide windows'

These errors are caused by an error source. There are four types of sources of error, according to Brown's Theory of Potential Sources of Error (2007): Interlingual error sources, intralingual transition, learning meaning, and communication strategies The researcher discovered all sources of error based on his study.

First is interlingual transfer which occurs in 30 error sentences. Interlingual transfer occurs as the influence of the student's first language when they translate the sentence into English. The students wrote in English sentence but they translate word by word based on Indonesian word order. Second is Intralingual transfer as the influence of the target language itself. In this research, intralingual occurs 55 times in 55 error sentences. In most cases it causes by the student's inability of English sentence's structure/grammar and intralingual transfer source of error has the major contributions in this research. Third is context of learning. The findings indicate that students sometimes make mistakes as a result of a teacher's misinformation or as a result of a pattern that was memorized in a drill but was not properly contextualized. There were 14 error sentences in this study that were triggered by the learning context. The third point to consider is communication methods. It has much to do with the student's learning style. Learners evidently made use of production strategies in order to enhance getting their message across and in this research there were 8 error sentences which are caused by communication strategies.

\section{Conclusion}

Based on the findings, it can be concluded that twenty seven data's from the student's descriptive text contain all type of error. It showed that students made 107 error sentences which consist of 44 errors of omission, 12 errors of addition, 39 errors of misformation and 12 errors of misordering and omission was the most frequent of error found.

The results show that all source types of error are causing the student's error in writing descriptive text. The researcher found their 107 error sentences consist of 30 error sentences which are caused by interlingual transfer, 55 error sentences which are caused by intralingual transfer, 14 error sentences.

\section{References}

Afifuddin. (2016). An Analysis of Students' Errors in Writing Descriptive Texts. University of Syiah Kuala, Banda Aceh.English Education Journal (EEJ),7 (1):130139.

Azar, B. S. (2003). Fundamental of English Grammar 3-rd edition. New York: Pearson Education, Inc.

Clouse, B. F. (2003). Pattern for a Purpose. Mc Graw-Hill Companies, Inc. 
Brown, H.D. (2007). Principle of Language Learning and Teaching, fifth edition. New York: Pearson Education, Inc.

Fatmawati, I. (2016). Grammatical Error in Descriptive Text Made by Eight Graders of Olympiad and Bilingual Student. Thesis. Malang: Maulana Malik Ibrahim State Islamic University of Malang.

Hedge, T. (2000). Teaching and Learning in the Language Classroom. New York: Oxford University Press.

Husna, L., Zainil., \&Rozimela, Y. (2013). An analysis of student writing skill in Descriptive Text at Grade XI IPA 1 of MAN 2 Padang. Journal of English Language Teaching. 1(2):56.

Malang, U. N. (2017). Pedoman Penulisan Karya Ilmiah. Malang: Universitas Negeri Malang.

Muhsin, M.A. (2016). Analyzing the Students Error in Using Simple Present (a case study at Junior High School of Makassar). Humanities and Social Science Journal. 82-89.

Novita, R. (2014). An Analysis of Grammatical Errors in the 1st Year Students'Writings at English Department, Andalas University. Vivid Journal. 3 (2):3.

Riyanto, S. Emilia and Leila. (2010). An Effective Way to Master English. Yogyakarta: Pustaka Pelajar.

Rustipa, K. (2011). Contrastive Analysis, Error Analysis, Interlanguage and The Implication to Language Teaching. Ragam Jurnal
Pengembangan Humanior. 11 (1):18-20.

Sahal, V. (2018). Student's Error in Using Present Tense in Writing Descriptive Text (A Study at MTS Jeumala Amal, Lueng Putu). Thesis. Banda Aceh: Faculty of Education and Teacher Training Ar-Raniry Islamic University Banda Aceh.

Sari, E. M. (2016). Interlingual Error and Intralingual Errors Found in Narrative Text Written by EFL Students in Lampung. Journal of Education. Vol.1 No.2:87-95.

Sugiyanto. (2017). Metode Penelitian. Bandung: Alfabeta.

Syakur, A., \&Rakhmawati, Y. (2014). An Error Analysis of Using Simple Present Tense in Descriptive Writing Text Among the Eight Grade Students of SMP IT Baitul UlumTempelGempol. English Education Journal. 3(1): 32-33.

Toago, A.P, Usman,S., \&Mukrim. (2013). The Ability of Students to Apply Present Tense in Writing Descriptive Text. E-Journal of English Language Teaching (ELTS). 1 (2):1-3.

Wardiman, A., Masduki., \& Sukirman. (2008). English In Focus. Jakarta: Pusat Perbukuan Departemen Pendidikan Nasional.

Widiati, U and Cahyono, B.Y. (2007). The Teaching of EFL Writing in Indonesian Context the State of the Art. Journal of Education. 13 (3):139- 150. 